\title{
Hubungan Preeklamsia Dengan Kejadian Persalinan Preterm di Rumah Sakit Umum Kabupaten Tangerang
}

\author{
Nurhayati \\ Jurusan Kebidanan Poltekkes Kemenkes Jakarta I \\ Email : nurhayatisamlawi@gmail.com
}

\begin{abstract}
Abstrak
Insiden kelahiran preterm di negara berkembang adalah (5\%-7\%) per 1000 kelahiran hidup dan prevalensi kelahiran preterm di Indonesia adalah (18,5\%). Preeklampsia merupakan salah satu penyebab angka kesakitan dan kematian ibu dan janin yang cukup tinggi di Indonesia. Preeklampsia umumya terjadi setelah kehamilan 20 minggu. Tujuan: Mengetahui hubungan preeklampsia terhadap kejadian persalinan preterm dan factor -faktor lain yang berpengaruhi kelahiran preterm. Metode: Penelitian observasional dengan rancangan case control di Rumah Sakit Umum Tangerang. Total kasus ada 90 orang (ibu melahirkan bayi tunggal pada usia kehamilan 20-36 minggu) dan kontrol ada 100 orang (ibu melahirkan bayi tunggal pada usia kehamilan $\geq 37$ minggu). Analisis univariabel, bivariabel dengan uji statistik Chi Square pada tingkat kemaknaan $\mathrm{p}<0.05,95 \%$ CI. Analisis multivariabel dengan model regresi logistik digunakan untuk memperkirakan odds ratio dan 95\% CI risiko preeklampsia/eklampsia terhadap kejadian kelahiran preterm. Hasil: Ibu dengan preeklampsia ringan dan preeklampsia mempunyai risiko untuk terjadi kelahiran preterm (OR:3,85; 95\% CI: 2,06-6,50) dibanding tidak preeklampsia. Faktor-faktor lain yang berpengaruh terhadap kejadian kelahiran preterm adalah riwayat persalinan preterm dan antenatal care. Kesimpulan: Ibu dengan preeklampsia mempunyai resiko untuk terjadi kelahiran preterm. Kejadian kelahiran preterm juga dipengaruhi oleh riwayat persalinan preterm dan antenatal care.
\end{abstract}

Kata kunci: preeklamsia dan persalinan preterm

\begin{abstract}
The incidence of preterm birth in developing countries is (5\% -7\%) per 1000 live births and the prevalence of preterm births in Indonesia is (18.5\%). Preeclampsia is one of the causes of high maternal and fetal morbidity and mortality rates in Indonesia. Preeclampsia generally occurs after 20 weeks of pregnancy. Objective: To determine the relationship of preeclampsia to the incidence of preterm labor and other factors affecting preterm birth. Method: An observational study with a case control design at the Tangerang General Hospital. The total cases were 90 people (mothers gave birth to a single baby at 20-36 weeks 'gestation) and there were 100 controls (mothers gave birth to a single baby at $\geq 37$ weeks' gestation). Univariable, bivariable analysis with Chi Square statistical test at significance level $\mathrm{p}<0.05$, 95\% CI. Multivariable analysis with logistic regression models was used to estimate the odds ratio and 95\% CI risk of preeclampsia / eclampsia in the incidence of preterm birth. Results: Mothers with mild preeclampsia and preeclampsia had a risk of preterm birth (OR: 3.85; 95\% CI: 2.06-6.50) compared to non-preeclampsia. Other factors that influence the incidence of preterm birth are a history of preterm and antenatal care. Conclusion: Mothers with preeclampsia are at risk for preterm birth. The incidence of preterm birth was also influenced by a history of preterm and antenatal care
\end{abstract}

Keywords: preeclampsia and preterm labor

\section{Pendahuluan}

Perkembangan anak di dalam kandungan sangat tergantung pada kondisi kesehatan ibu. Kesehatan ibu yang terganggu akan mengakibatkan gangguan pada perkembangan janin. Salah satu gangguan perkembangan janin adalah preterm birth. Tucker \& McGuire (2004) mendefinisikan preterm birth/kelahiran preterm adalah kelahiran bayi sebelum usia kehamilan 37 minggu (termasuk 36 minggu 6 hari). Persalinan preterm adalah persalinan yang terjadi pada kehamilan kurang dari 37 minggu (antara 20-37 minggu) atau dengan berat janin kurang dari 2500 gr (Saifuddin dkk., 2015).

Salah satu faktor penyebab terjadinya berat badan lahir rendah (BBLR) adalah faktor penyakit ibu. Penyakit yang berhubungan langsung dengan kehamilan misalnya 3 preeklampsia/eklampsia, hiperemesis 
gravidarum, perdarahan antepartum, dan infeksi selama kehamilan (infeksi kandung kemih dan ginjal) (Proverawati dan Ismawati, 2010).

Menurut Kramer (2003), kelahiran preterm di negara berkembang dapat dipicu oleh banyak faktor risiko yang antara lain adalah infeksi genitourinaria, kehamilan ganda, pregnancy induced hypertension (PIH), Body Mass Index (BMI) sebelum hamil rendah, inkompetensi servik, riwayat pernah melahirkan preterm, abruptio plasenta, pekerja berat dan merokok. Selain itu, faktor risiko yang memicu terjadinya kelahiran preterm adalah preeklampsia/eklampsia, usia ibu $<20$ tahun atau >35 tahun, jarak kehamilan dan bersalin terlalu dekat, gravida (Demissie, et al., 2001), paritas, riwayat abortus, pendidikan ibu (Offord, 2002) dan antenatal care (ANC) yang kurang (Saifuddin, dkk., 2015). Faktor risiko lain yang juga berperan dalam kejadian kelahiran preterm adalah genetik, interval kehamilan yang pendek ( $<6$ bulan) (Bale et al., 2003). Kelahiran preterm berbeda dengan berat bayi lahir rendah (BBLR), walaupun dalam kelahiran preterm sering disertai dengan berat badan yang rendah. Bayi dengan berat badan lahir rendah dapat disebabkan oleh istilah kecil untuk usia kehamilan (small of gestation age $=\mathrm{SGA}$ ) yang mengarah ke pertumbuhan janin terganggu (intrauterine growth restriction=IUGR) atau lahir preterm. Keadaan ini tergantung pada umur kehamilan.

Penelitian Arun Jeyabala di USA menyebutkan adanya efek preeklampsia terhadap janin dan neonatus. Sekitar 12-25\% mengakibatkan terbatasnya pertumbuhan janin dan kecil untuk usia kehamilan serta kelahiran prematur. Sehingga dapat meningkatkan morbiditas dan mortalitas neonatal (Jeyabala A, 2013). Tanpa perawatan dan manajemen yang tepat, preeklampsia akan menyebabkan beberapa komplikasi kesehatan yang serius termasuk persalinan preterm/prematur dan kejadian kematian. Preeklmsia dapat terjadi pada setiap wanita hamil, namun lebih banyak dialami oleh mereka yang baru hamil pertama kali (Epigee, 2005).

Ibu hamil dengan preeklampsia dapat menjadi berbahaya untuk ibu dan bayi yang mana kadang - kadang perlu melahirkan bayi sebelum usia 36 minggu kehamilan. Hal ini dapat menyebabkan munculnya masalah perkembangan dan kejadian kematian bayi (Epigee, 2005).

\section{Tujuan}

Mengetahui hubungan preeklampsia terhadap kejadian persalinan preterm dan faktor-faktor lain yang berpengaruhi kelahiran preterm.

\section{Metode}

Penelitian observasional dengan rancangan case control di Rumah Sakit Umum Tangerang. Total kasus ada 45 orang (ibu melahirkan bayi tunggal pada usia kehamilan 20-36 minggu) dan kontrol ada 45 orang (ibu melahirkan bayi tunggal pada usia kehamilan $\geq 37$ minggu). Analisis univariabel, bivariabel dengan uji statistik Chi Square pada tingkat kemaknaan $\mathrm{p}<0.05$, 95\% CI. Analisis multivariabel dengan model regresi logistik digunakan untuk memperkirakan odds ratio dan 95\% CI risiko preeklampsia/eklampsia terhadap kejadian kelahiran preterm.

\section{Hasil}

Tabel 1. Karakteristik Variabel Persalinan Preterm di Rumah Sakit Umum Kab Tangerang

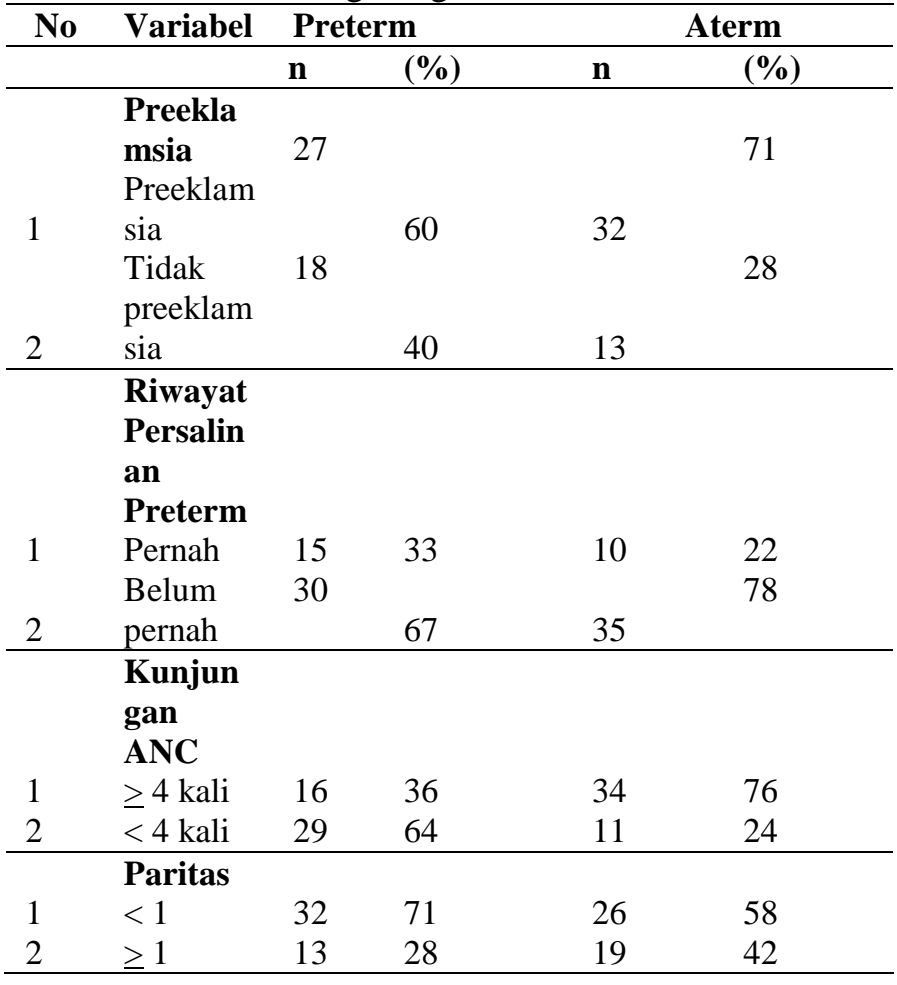

Dari table di atas dapat dilihat bahwa karakteristik responden disajikan berdasarkan kelompok kasus (persalinan preterm) dan kelompok control (persalinan paterm) yang terdiri dari preeklamsia, riwayat persalinan 
atem, kunjungan ANC dan paritas. Pada kasus persalinan preterm sebanyak $60 \% \mathrm{ibu}$

mengalami preeklamsia, $67 \%$ tidak mempunyai persalinan pretem, $64 \%$ melakukan kunjungan anc secara rutin sebanyak lebih dari 4 kali selama kehamilan dan $71 \%$ mempunyai paritas anak pertama.

Tabel 2. Pengaruh Variabel preeklamsia, riwayat persalinan premature dan kunjungan ANC di Rumah Sakit Umum Kab. Tangerang

\begin{tabular}{llllllllll}
\hline \multirow{2}{*}{ No } & Variabel & \multirow{2}{*}{$\mathrm{B}$} & $\mathrm{SE}$ & Wald & $\mathrm{df}$ & $\mathrm{Sig}$. & $\mathrm{Exp}$ & \multicolumn{2}{c}{$95,0 \%$ C.I.for EXP(B) } \\
\cline { 8 - 10 } & & & & & & & $(\mathrm{B})$ & Lower & Upper \\
\hline 1 & Preeklamsia & .907 & .529 & 4.446 & 1 & 0.001 & 3.85 & 2.06 & 6.50 \\
\hline 2 & Riwayat preterm & .457 & .482 & 3.456 & 1 & 0.005 & 3.06 & 1.13 & 8.24 \\
\hline 3 & Kunjungan ANC & .524 & .356 & 3.845 & 1 & 0.023 & 4.26 & 1.21 & 19.58 \\
\hline
\end{tabular}

Hasil analisis menunjukkan bahwa preeklampsia secara statistik mengarah kepada kejadian kelahiran preterm, dengan risiko 3,85 kali lebih besar dibandingkan dengan tidak mengalami preeklampsi. Hasil penelitian ini mendukung penelitian yang telah dilakukan sebelumnya antara lain Chen, et al. (1996) yang meneliti di populasi Chinese dengan hasil penelitian bahwa preeklampsia merupakan faktor yang mempengaruhi persalinan preterm (OR: 3,48).

Secara teori, patofisiologi preeklampsia adalah terjadi disfungsi endotelial vaskuler dan perubahan patofisiologi yang terjadi adalah spasme pembuluh darah, peningkatan tekanan darah. Perubahan yang terjadi dalam sistem kardiovaskuler yang berupa spasme arteriol dapat mengganggu aliran darah uteroplasental. Plasenta banyak mendapat suplai darah dari arteri uteroplasental dan secara keseluruhan berkembang pada trimester pertama dan kedua kehamilan. Menurunnya aliran darah ke plasenta mengakibatkan gangguan fungsi plasenta. Spasme arteriol yang mendadak dapat menyebabkan asfiksia berat. Jika spasme berlangsung lama akan mengganggu pertumbuhan janin. Jika terjadi peningkatan tonus dan kepekaan uterus terhadap rangsang dapat menyebabkan partus prematurus. Pada eklampsia dapat terjadi kejang sehingga dapat menyebabkan kontraksi uterus yang memungkinkan untuk terjadinya kelahiran preterm. Menurut Weismiller (1999), ada pengaruh fetal fibronectin dalam kejadian preterm birth. Dalam kehamilan awal seperti saat implantasi, fetal fibronectin akan normal dalam cairan servikovaginal. Setelah 24 minggu kehamilan, keberadaan fetal fibronectin mengindikasikan pecahnya membran fetal dari desidua yang berisiko tiga kali untuk melahirkan preterm pada wanita dengan kontraksi uterus.

Pada variabel riwayat persalinan preterm memiliki hubungan yang bermakna dengan kelahiran preterm. Ibu yang pernah mengalami persalinan preterm mempunyai risiko 3,06 kali lebih besar untuk melahirkan preterm dibandingkan dengan ibu yang belum pernah mengalami persalinan preterm. Hasil penelitian dari Cunningham et al. (2014) yang menyatakan bahwa wanita yang pernah melahirkan jauh sebelum aterm (abortus atau preterm) lebih besar kemungkinannya untuk mengalami hal yang sama sekalipun tidak ditemukan faktor predisposisi lainnya. Mekanisme biologi bagaimana riwayat persalinan preterm mempengaruhi kejadian kelahiran preterm belum jelas, namun peneliti berpendapat bahwa faktor lain ikut memberikan pengaruh untuk terjadinya kelahiran preterm berulang seperti stress psikologis, ras, etnik, faktor medik dan non medik.

Hasil analisis penelitian menunjukkan bahwa ANC yang diwakili dengan jumlah kunjungan 
memiliki hubungan yang bermakna dengan kelahiran preterm. Ibu yang melakukan kunjungan ANC kurang dari 4 kali mempunyai risiko 4,88 kali lebih besar untuk melahirkan preterm dibandingkan dengan ibu yang melakukan kunjungan ANC lebih dari 4 kali. Tidak diketahui dengan pasti bagaimana mekanisme biologi antenatal care mempengaruhi secara langsung terhadap preterm birth (Shah \& Ohlsson, 2002). Kunjungan pemeriksaan kehamilan yang rutin dan tepat akan segera diketahui ada atau tidaknya masalah dalam kehamilan. Hal ini sesuai dengan tujuan antenatal care yaitu mengenal dan menangani sedini mungkin penyulit yang terdapat saat kehamilan, saat persalinan dan kala nifas; mengenal dan menangani penyakit yang menyertai kehamilan, persalinan dan kala nifas; memberikan nasehat dan petunjuk yang berkaitan dengan kehamilan, persalinan, kala nifas, laktasi dan aspek keluarga berencana; menurunkan angka kesakitan dan kematian ibu dan perinatal (Saifuddin dkk., 2015).

\section{Kesimpulan}

Dari hasil penelitian variabel preeklamsia, riwayat persalinan premature dan kunjungan ANC mempengaruhi secara bersama-sama terhadap kejadian persalinan preterm di Rumah Sakit Umum Kab. Tangerang.

\section{Saran}

Asuhanan kebidanan pada masa hamil harus dilakukan secara komprehensif sehingga dapat diketahui adanya penyulit dalam kehamilan. Pelayanan kegawatdaruratan kebidanan di rumah Sakit harus dapat digunakan sebagai sarana dalam penanganan kasus kegawatdaruaratan kebidanan.

\section{Ucapan Terimakasih}

Ucapan terimakasih kami sampaikan

Direktur rumah Sakit Umum Kabupaten Tangerang dan responden yang terlibat dalam penelitian ini.

\section{Daftar Pustaka}

Bale, J.R., Stoll, B.J. \& Lucas, A.O. eds. Committee on Improving Birth
Outcomes Board on Global Health. (2003) Improving Birth Outcomes: Meeting The Challenge In The Developing World. Institute of Medicine. The National Academies Press. Washington

Chen, C.P., Wang, K.G., Yang, Y.C. \& See, L.C. (1996) Risk Factors for Preterm Birth in An Upper Middle Class Chinese Population. Eur J Obstet Gynecol Reprod Biologi

Cunningham, F.G., MacDonald, P.C. \& Gant, N.F., Alih Bahasa Suyono, J. \& Hartono, A., Ronardy, D.H. ed. (2014) Obstetri Williams. Edisi 18. Penerbit Buku Kedokteran. EGC. Jakarta.

Epigee. (2005) Preeclampsia. [Internet]. Available from:http://www. epigee.org/pregnancy/ preeclampsia.html

Offord, D. (2002) "Keeping Score" on Kids in Hamilton.How Hamilton"s Children are Starting Out: Outcomes of Birth. Canadian Centre for Studies of Children at Risk. Canada; pp: 79-133 [Internet]. Available from:http://www.offordcentre.com/kee pscore/reports/ section4.WEB.pdf\#search $=$ 'What $\% 20$ Does\%20the\%20Literature\%2 0Tell\%20Us'

Saifuddin AB, Rachimhadhi T, Winknjosastro GH. Ilmu Kebidanan Sarwono Prawirohardjo Edisi Keempat. Jakarta: Yayasan Bina Pustaka Sarwono Prawirohardjo. 2015

Shah, P \& Ohlsson, A. (2002) Literature Review of Low Birth Weight, Including Small for Gestational Age and Preterm Birth.Toronto Public Health. Toronto

Weismiller. D.G. (1999). Preterm Labor. Can Fam Physician. Vol. 59. No. 3. [Internet]. Available from: <http://www.aafp.org/ afp/ 990201ap/ 593.html $>$ 